context of the clinical situation, may not be as "nonsensical" or difficult to understand as Dr. O'Sullivan might suggest.

Donald R. Miller MD FRCPC

Raymond J. Martincau MD FRCPC

Department of Anaesthesia

Ottawa General Hospital

University of Ottawa

Ottawa, Ontario

REFERENCES

1 Miller DR, Martineau RJ. Bolus administration of esmolol for the treatment of intraoperative myocardial ischaemia. Can J Anaesth 1989; 36: 593-7.

2 Gobel FL, Nordstrom LA, Nelson RR. The rate pressure product as an index of myocardial oxygen consumption during exercise in patients with angina pectoris. Circulation 1978; 57: 549-56.

3 Cokkinos $D V$, Voridis $E M$. Constancy of rate-pressureproduct in pacing induced angina pectoris. $\mathrm{Br}$ Heart $\mathrm{J}$ 1975; 38: 39-42.

4 Buffington $C W$. Hemodynamic determinants of ischemic myocardial dysfunction in the presence of coronary stenosis in dogs. Anesthesiology 1985; 63: 65I-2.

\section{Anaesthesia and medico-legal concerns ${ }^{1}$}

To the Editor:

It is now becoming more obvious that proper communication with the patient is an essential component in the provision of complete medical care. This issue is raised and further discussed in the above editorial. Throughout my career as an anaesthetist, it had always been my feeling that the preoperative visit made to the patient in hospital, the evening before surgery, was generally equally unsatisfactory to both patient and anaesthetist. For the most part, it would be ludicrous and inappropriate to assume that proper informed consent could be obtained after such brief encounters.

My practise has now changed and is mostly to do with diagnostic and therapeutic anaesthesia. All patients are seen initially as a consultation during which treatment is planned. Full disclosure is made to the patient with respect to planned therapy, indications, contraindications, and risk. Patients are thus informed and educated about anaesthesia. It is my opinion that for the patient who is contemplating surgery involving the administration of anaesthesia, after he/she has consulted with the surgeon, the next stop should be at the office of a consulting anaesthetist. This should be well in advance of the date of surgery. It is obvious that practising in this manner provides better patient care, decreases the likeli- hood of an uninformed and disgruntled patient, and raises the level of professionalism for the anaesthetist.

\section{Edward J. Sheffman MD FRCPC DABA FACA}

\section{REFERENCE}

1 Anaesthesia and medico-legal concerns. Can J Anacsth 1990; 37: 1-3.

\section{Epidural air-filled bubbles and unblocked segments}

To the Editor:

I read with interest the letter by Boezaart and Levendig ${ }^{1}$ reporting an unblocked segment due to epidural air-filled bubbles demonstrated by peridurography. While this may serve to illustrate one of the problems of using loss of resistance to air instead of saline, it also illustrates a consequence of injecting an unnecessarily large volume of air. I estimate from the peridurogram that at least $5 \mathrm{ml}$ had been injected. Was this necessary? Furthermore, I would question the suggestion that the catheter migrated into the subarachnoid space some distance from the site of entry into the epidural space as illustrated. It has been shown that migration of the catheter through the dura is very unlikely to occur, if at all, unless the dura has already been breached by the needle. ${ }^{2}$ How was the "CSF" tested? The commonly used method in this situation is to test for glucose. It is not uncommon to be able to aspirate fluid from the epidural space some time after a top-up, and if tested, this fluid will be positive for glucose due to diffusion of glucose from the tissues of the epidural space into the top-up solution. ${ }^{3}$ As further evidence in support of subarachnoid placement of the catheter, the authors cite the "unexpected behaviour of the block." I suggest that satisfactory analgesia after $8 \mathrm{ml}$ of 0.25 per cent bupivacaine at the second lumbar interspace is entirely to be expected. Had the block lasted for three hours or more, or the spread been extensive, then subarachnoid placement may have been a possibility. Neither of these factors was mentioned. I submit that this was a completely normal epidural complicated only by an unblocked segment due to the use of an excessive amount of air.

Boyd H. Meiklejohn BSc MB ChB FFARCS

Dept. of Anaesthesia

Leicester Royal Infirmary

Leicester LE1 5WW, U.K. 


\section{REFERENCES}

1 Boezaart AP, Levendig BJ. Epidural air-filled bubbles and unblocked segments. Can J Anaesth 1989; 36: 603-4.

2 Hardy PAJ. Can epidural catheters penetrate dura matter? An anatomical study. Anaesthesia 1986; 41: 1146-7.

3 Scott $D B$. Test doses in extradural analgesia. $\mathrm{Br} J$ Anaesth 1979; $51: 808$.

\section{$R E P L Y$}

I am not sure what an "unnecessarily large volume of air" means as very small bubbles caused unblocked segments in the patients described by Dalens et al.' Since we have been using the technique of saline and air in the same syringe, as described by Wait, ${ }^{2}$ the problem of unblocked segments is almost nonexistent in our practice.

There can be no doubt that (a) the aspirated fluid was CSF (Table). Catheter migration is today a very well documented and widely accepted entity. ${ }^{3-5}$ Thus, I believe that the behaviour of the block was due to pressure differences at different anatomical sites and locations in the catheter following subarachnoid migration of the distal part of the catheter.

During the application of negative pressure to the aspirating syringe, CSF entered the catheter. When using multihole epidural catheters, Power and Thorburn ${ }^{6}$ demonstrated that flow is present at the proximal hole at low pressures, and appears at the middle and distal holes at higher pressures. They also proved the hypothesis that the pressure used to inject local anaesthetics during an epidural topup produces a differential flow from the holes in a multihole catheter. When multihole catheters are passed partially through the dura and arachnoid, the character of the blockade is determined by the differential exit flows from the three holes in the catheter. A slow rate of injection (which was used as we fractionated the local anaesthetic agent in 2 ml increments) will give an epidural block when the local anaesthetic exits from the catheter through the proximal hole. A more rapid rate of injection will cause a portion of the agent to enter the CSF through the distal hole causing a subarachnoid block.

Thus, I respectfully disagree with Dr. Meiklejohn. This was not a "completely normal epidural." The end result of the epidural turned out to appear completely normal because the

TABLE

\begin{tabular}{lll}
\hline & First aspirate & Second aspirate \\
\hline Volume $(\mathrm{ml})$ & 1.2 & 1.0 \\
Appearance & Clear & Clear \\
Colour & Clear & Clear \\
Turbidity & Nil & Nil \\
Clotting & Nil & Nil \\
Protein $\left(\mathrm{g}^{-1}\right)$ & 0.35 & 0.30 \\
Glucose $\left(\mathrm{mmol}^{-1}\right)$ & 3.1 & 2.9 \\
Chloride $\left(\mathrm{mmol}^{-1}\right)$ & 132 & 134 \\
White blood cells & Nil & Nil \\
Red blood cells & Occasional & Occasional \\
\hline
\end{tabular}

safety precautions of epidural anaesthesia were carefully adhered to.

Andre P. Boezaart

Johannesberg

South Africa

REFERENCES

I Dalens $B$, Bazin $J$, Haberer $J$. Epidural bubbles as a cause of incomplete analgesia during cpidural analgesia. Anesth Analg 1987; 66: 679-83.

2 Wait $C M$. Identification of the epidural space. Anaesthesia 1987; 43: 1231.

3 Hartrick CJ, Pither CE, Pae E, Raj P, Tomsick TA. Subdural migration of an epidural catheter. Ancsth Analg 1985; 64: 175-8.

4 Phillips DC, Macdonald $R$. Epidural catheter migration during labour. Anaesthesia 1987; 42: 661-3.

5 Abouleish $E$, Goldstein $M$. Migration of an extradural catheter into the subdural space. A case report. $\mathrm{Br} J$ Anaesth 1986; 58: 1194-7.

6 Power I, Thorburn J. Differential flow from multihole epidural catheters. Anaesthesia 1988; 43: 876-8.

We regret that Fig $1 b$ in the original letter was printed upside down. Editor.

\section{Surgery in Jehovah's Witnesses}

To the Editor:

We have read Wong and Jenkins' Surgery in Jehovah's Witnesses ${ }^{1}$ with interest. Much of the advice is sensible and well-balanced. However, we beg to disagree with their conclusion that "the surgeon and the anaesthetist" should "take the challenge" and accept that "the religious beliefs of Jehovah's Witnesses should be respected." This one-way traffic in respect of personal conviction pays no credence to the religious, or other, beliefs of the surgeon and anaesthetist.

We have decided that we will no longer administer an anaesthetic for surgery in a Jehovah's Witness who refuses to accept our belief that administration of blood products may be necessary to sustain that patient's life. We will, however, assist the surgeon to find another anaesthetist whose beliefs accord with the Jehovah's Witness. Anaesthetists find challenge enough in the attempt to provide safe anaesthesia without additional risks being imposed by the patient.

A recent experience of having to allow a previously healthy, young, Jehovah's Witness to die on the operating table, as the result of unfortunate surgical bleeding after elective surgery which caused the haemoglobin concentration to fall to $9.0 \mathrm{~g} \cdot \mathrm{L}^{-1}$ is not an occurrence which we 